\title{
STRATEGI OPTIMALISASI FUNGSI PELABUHAN PERIKANAN DALAM PEMASARAN HASIL TANGKAPAN DI PPP LEMPASING
}

\section{Optimization of Fishing Port Function In Marketing of Fish Catch In Lempasing Coastal Fishing Port}

\author{
Oleh: \\ Aprilia Syah Putri ${ }^{*}$, Iin Solihin ${ }^{2}$, Eko Sri Wiyono ${ }^{2}$ \\ ${ }^{1}$ Mahasiswa Program Studi Teknologi Perikanan Laut \\ ${ }^{2}$ Staf Pengajar Program Studi Teknologi Perikanan Laut \\ Korespondensi: apriliasyahputri030309@gmail.com
}

\begin{abstract}
ABSTRAK
Provinsi Lampung memiliki sumberdaya perikanan laut yang sangat besar mencapai 388.000 ton/tahun. Pelabuhan Perikanan Pantai (PPP) Lempasing merupakan salah satu pelabuhan terbesar di provinsi lampung yang tidak terlepas dari aktivitas pemasaran hasil tangkapan. Banyak permasalahan yang terjadi pada sistem pemasaran di pelabuhan perikanan untuk mencapai pemasaran yang efisien sehingga diperlukan strategi optimalisasi fungsi pelabuhan perikanan. Penelitian ini bertujuan untuk mengetahui tingkat efisiensi pemasaran hasil tangkapan pada 5 komoditas ikan dan merumuskan strategi optimalisasi fungsi pelabuhan perikanan dalam pemasaran hasil tangkapan di PPP Lempasing. Metode yang digunakan adalah metode survey dan metode wawancara yang meliputi kepala pelabuhan, nelayan dan pedagang. Metode analisis yang digunakan yaitu analisis efisiensi pemasaran dan analisis SWOT dengan metode USG. Hasil penelitian menunjukkan bahwa hanya cumi-cumi yang memiliki nilai efisien yang tinggi (3,33\%). Strategi optimalisasi fungsi pelabuhan perikanan meliputi 3 strategi utama yaitu meningkatkan mutu hasil tangkapan pasca panen, peningkatan higenitas dan sanitasi di area sekitar tpi serta peningkatan sosialisasi kepada pedagang dan nelayan terkait mutu ikan.

Kata Kunci: analisis SWOT, efisiensi pemasaran, metode USG, Pelabuhan Perikanan, PPP Lempasing, strategi.

\section{ABSTRACT}

Lampung Province has a fisheries resources around 388.000 ton/years. Lempasing Coastal Fishing Port (PPP) is the largest fishing port in Lampung Province. Fishing port is inseparable from the marketing activities of catch. The marketing activity of catch is one of the most important fishing business activities in fishing port. The purpose of this research was to determine the efficiency of marketing channels of five fish commodities, and to formulate the optimization strategy of fishing port function. The research was conducted through survey method and interview method with related parties include the head of harbor, fishermen and retailers. An efficiency analysis and SWOT (Strength Weakness Opportunities and Threath) with USG method was used in this research. From 5 commodities that only squid had high value of efficient (3,33\%). There were three strategies to optimize the function of the fishing port, improvement of post-harvest catch quality, increasing in hygiene and sanitation in the area around the place for fish marketing or TPI and increasing in socialization to fish traders and fishermen related to fish quality.
\end{abstract}

Keywords: SWOT analysis, marketing efficiency, USG method, fishing port, Lempasing coastal fishing port, strategy. 


\section{PENDAHULUAN}

Pelabuhan perikanan merupakan pusat pemasaran hasil tangkapan, dimana peran dan sarananya sangat penting dalam perekonomian suatu pelabuhan yaitu mulai dari pendaratan sampai dengan pemasaran hasil tangkapan (Lubis 2011). Fungsi pelabuhan perikanan dalam pemasaran hasil tangkapan mencakup ketersediaan fasilitas, pelayanan dan ketersediaan sistem informasi. Ketiga indikator ini sangat penting dalam suatu pelabuhan perikanan. Adanya fasilitas, pelayanan dan sistem informasi yang baik di PPP Lempasing tentu akan memperlancar kegiatan pemasaran. Namun sebagian fasilitas yang mendukung pemasaran di PPP Lempasing ada yang tidak berjalan aktif, adanya keterbatasan mengenai jumlah maupun kelengkapan fasilitas, lemahnya pengelolaan serta terbatasnya sarana dan prasarana transportasi, lemahnya pelayanan jasa dan adanya keterbatasan dalam sistem informasi yang menghambat kelancaran suatu fungsi pelabuhan perikanan di PPP Lempasing. Sehingga diperlukan suatu strategi agar memiliki arah yang jelas dalam mencapai sasaran yang diinginkan. Pada prinsipnya PPP Lempasing perlu membuat strategi optimalisasi fungsi pelabuhan perikanan dalam pemasaran hasil tangkapan baik dari fasilitasnya, pelayanannya dan sistem informasi. Sehingga fungsi pelabuhan perikanan dapat berfungsi secara optimal.

Penelitian ini berfokus pada lima komoditas ikan yaitu ikan kurisi (Nemipterus sp), cumi-cumi (Loligo sp), ikan tongkol (Euthynnus affinis), ikan kembung (Rastelliger spp) dan ikan kwee (Gnathanodon speciosus) dengan pertimbangan bahwa ikan tersebut merupakan ikan segar yang dominan dipasarkan di PPP Lempasing. Sifat khas suatu komoditas ikan ini adalah mudah mengalami pembusukan (perishable), sehingga menuntut para pedagang dan nelayan untuk melakukan tindakan penanganan yang cepat baik dalam proses produksi maupun selama pemasaran, guna menghindari turunnya kualitas dan harga ikan tersebut. Sistem pemasaran hasil tangkapan merupakan suatu kesatuan dari lembaga atau pelaku pemasaran yang berperan melakukan fungsi dalam pemasaran. Usaha perikanan tangkap di PPP Lempasing sampai saat ini masih didominasi oleh usaha perikanan tangkap skala kecil dengan tingkat produktivitas dan efisiensi usaha serta pendapatan yang masih rendah (DPT 2004).

Penanganan hasil tangkapan sangat mempengaruhi terhadap tingkat efisiensi suatu komoditas ikan. tingkat efisiensi berpengaruh terhadap biaya pemasaran dan harga ikan di tingkat pengecer. Efisien memiliki makna bahwa sistem pemasaran mampu memproduksi dan memasarkan produk dengan harga relatif murah untuk kualitas produk yang sama ditingkat konsumen. Masalah pemasaran adanya keterlibatan pihak ketiga (pedagang perantara) yang turut memperumit pola pemasaran yang efisien, dimana dalam suatu aktivitas pemasaran tidak lepas dari lembaga/ pelaku pemasaran.

Komoditi perikanan berfluktuasi menurut jumlah produksi dan harga. Fluktuasi produksi disebabkan hasil tangkapan yang tergantung pada musim, sedangkan fluktuasi harga diakibatkan oleh pergeseran permintaan dan penawaran ikan segar. Harga ikan segar hasil tangkapan akan menentukan perilaku pasar usaha tersebut. Apabila produksi harga rendah, maka pemasaran harus baik dan efisien (Yulianto et al. 2013). Penelitian ini bertujuan untuk menentukan tingkat efisiensi pemasaran dan merumuskan strategi optimalisasi fungsi pelabuhan perikanan dalam pemasaran hasil tangkapan.

\section{METODE PENELITIAN}

Penelitian dilaksanakan pada bulan Juli hingga September tahun 2016 di PPP Lempasing Bandar Lampung. Data yang dikumpulkan meliputi data primer dan data sekunder. Data sekunder diperoleh melalui instansi atau lembaga yang terkait. Data primer dikumpulkan dengan menggunakan metode purposive sampling melalui pengamatan langsung terhadap berbagai aktivitas yang dilakukan di pelabuhan yaitu wawancara terhadap lima nelayan, lima pedagang pasar pelabuhan, lima pedagang pasar daerah, lima pedagang distributor, lima pedagang pengecer dan pihak kepala pelabuhan. Data dan jenis data yang diambil dapat dilihat pada Tabel 1. 
Tabel 1 Pengumpulan data penelitian

\begin{tabular}{lll}
\hline Tujuan & Data yang diambil & Jenis Data \\
\hline Tingkat efisiensi pemasaran hasil & Harga es & Data Primer dan \\
tangkapan & Harga solar & Data Sekunder \\
& Harga Bensin & \\
& Harga ikan per tingkat lembaga & \\
& pemasaran & \\
& Volume ikan yang akan & \\
& dipasarkan per lembaga pemasaran & \\
& Harga buruh angkut & \\
& Harga air bersih & \\
& & \\
Optimalisasi fungsi pelabuhan & Data fasilitas di PPP Lempasing & Data Primer dan \\
perikanan dalam pemasaran hasil & Pelayanan & Data Sekunder \\
tangkapan & Sistem informasi & \\
\hline
\end{tabular}

Tingkat efisiensi pemasaran dianalisis dengan mengacu pada Anwar (1976) yaitu:

$$
\text { Eps }=[\mathrm{Bp} / \mathrm{HE}] \mathrm{x} 100 \%
$$

Keterangan :

Eps : Efisiensi pemasaran hasil tangkapan (\%)

Bp : Biaya pemasaran $(\mathrm{Rp} / \mathrm{kg})$

$\mathrm{HE} \quad$ : Harga eceran produk akhir $(\mathrm{Rp} / \mathrm{kg})$

Kriteria tingkat efisiensi dengan mengacu Anwar (1976) yaitu:

a. iika Eps $\leq 5 \%$ maka saluran pemasaran dianggap efisien.

b. Jika Eps $\geq 5 \%$ maka saluran pemasaran dianggap tidak efisien.

Selain itu, Perumusan strategi optimalisasi fungsi pelabuhan perikanan dalam pemasaran hasil tangkapan dianalisis dengan SWOT (Strength Weakness Opportunity Treath) dengan mempertimbangkan faktor lingkungan internal berupa strengths dan weaknesses serta lingkungan eksternal berupa opportunities dan threats dalam suatu sistem pemasaran (Rangkuti 2011).

Proses yang harus dilakukan dalam pembuatan analisis SWOT yaitu: 1) tahap pengambilan data dengan identifikasi faktor internal dan faktor eksternal; 2) tahap analisis dengan pembuatan matriks internal eksternal dan pembuatan matriks SWOT; 3) tahap perumusan strategi. Setelah melakukan perumusan strategi maka untuk mendapatkan skala prioritas dari strategi yang didapatkan yaitu dengan mengunakan metode USG (Urgensi Seriousness Growth). Metode USG ini dilakukan oleh para pakar yang ahli dibidangnya. USG adalah salah satu alat yang digunakan untuk menyusun urutan prioritas suatu strategi yang harus diselesaikan. Penentuan tingkat kepentingan, keseriusan dan perkembangan suatu strategi dengan menentukan skala likert yaitu nilai antara 1 sampai 5. Strategi yang memiliki total skor tertinggi merupakan suatu strategi yang menjadi prioritas. Dimana skala $1:$ sangat rendah, 2 : rendah, 3 : sedang, 4 : tinggi, 5 : sangat tinggi (Asmoko 2013).

\section{Urgency}

Seberapa mendesak suatu strategi tersebut yang harus dibahas jika dikaitkan dengan waktu yang tersedia serta seberapa keras tekanan waktu tersebut untuk memecahkan strategi yang menyebabkan suatu permasalahan tersebut.

\section{Seriousness}

Seberapa serius suatu strategi tersebut perlu dibahas, jika dikaitkan dengan akibat timbul dengan penundaan pemecahan masalah yang menimbulkan suatu permasalahan tersebut atau akibat yang 
menimbulkan masalah-masalah lain kalau masalah penyebab suatu permasalahan tidak dipecahkan. Perlu dimengerti bahwa dalam keadaan yang sama, suatu masalah yang dapat menimbulkan masalah lain adalah lebih serius bila dibandingkan dengan suatu masalah lain yang berdiri sendiri.

3. Growth

Seberapa mungkin suatu strategi tersebut menjadi berkembang dikaitkan kemungkinan masalah penyebab suatu maslah akan makin memburuk jika dibiarkan.

\section{HASIL}

\section{Tingkat Efisiensi Pemasaran}

Efisiensi pemasaran ikan tidak lepas dari saluran pemasaran. Ikan kurisi, tongkol, kembung dan ikan kwee melewati pola saluran pemasaran yang sama yaitu nelayan menjual hasil tangkapan ke pedagang pasar pelabuhan, kemudian dari pedagang pasar pelabuhan ikan dijual ke pedagang pasar daerah, dari pedagang pasar daerah ikan dijual ke pedagang distributor dan dari pedagang distributor dijual ke pedagang pengecer hingga sampai pada konsumen akhir. Berbeda untuk ikan cumi-cumi, pola saluran pemasaran ikan cumi-cumi memiliki pola saluran pemasaran yang sama pada keempat ikan lainnya, namun tidak melewati pedagang pasar daerah.

Pada setiap komoditas ikan memiliki harga dan pola pemasaran yang berbeda-beda. Harga kelima komoditas ikan per lembaga pemasaran dapat dilihat pada Tabel 2.

Tabel 2 Harga hasil tangkapan per lembaga pemasaran

\begin{tabular}{lccccc}
\hline \multirow{2}{*}{ Lembaga Pemasaran } & \multicolumn{5}{c}{ Harga Komoditas Ikan (Rp/kg) } \\
\cline { 2 - 6 } & Kurisi & Cumi-cumi & Tongkol & Kembung & Kwee \\
\hline Nelayan & 16400 & 34400 & 19400 & 16400 & 29400 \\
Pedagang Pasar Pelabuhan & 17400 & 39400 & 23400 & 23400 & 32400 \\
Pedagang Pasar Daerah & 19400 & - & 24400 & 32400 & 34400 \\
Pedagang Distributor & 22400 & 44400 & 29400 & 34400 & 39400 \\
Pedagang Pengecer & 24400 & 54400 & 34400 & 39400 & 44400 \\
\hline Biaya Pemasaran (Rp/kg) & 2692 & 1812 & 1941 & 2131 & 2249 \\
\hline
\end{tabular}

Sumber : DKP PPP Lempasing (2016), diolah

Pada Tabel 2 terlihat bahwa harga untuk setiap komoditas ikan per lembaga atau pelaku pemasaran memiliki harga yang berbeda-beda. Harga disetiap lembaga pemasaran semakin meningkat mulai dari penetapan harga dari nelayan sampai pedagang pengecer. Peningkatan harga ini disesuaikan dengan harga kebutuhan penanganan ikannya yang meliputi biaya kebutuhan es, biaya penyimpanan, biaya transportasi maupun biaya kebutuhan air bersih. Biaya transportasi ke berbagai lokasi pemasaran membutuhkan biaya bahan bakar. Kemudian biaya buruh angkut di pelabuhan, baik biaya angkut hasil tangkapan setelah pembongkaran maupun biaya angkut ketika hasil tangkapan akan dipasarkan.

Jika dilihat pada Tabel 2 biaya pemasaran terendah yaitu pada ikan cumi-cumi sebesar Rp1 812 $/ \mathrm{kg}$. Biaya pemasaran ikan cumi-cumi rendah dari komoditas ikan lainnya, hal ini disebabkan karena saluran pemasaran yang dilalui ikan cumi-cumi ini pun berbeda. Cumi-cumi tidak melewati lembaga pemasaran pedagang pasar daerah, hal ini karena untuk ikan cumi-cumi dalam waktu yang relatif lama bobot tubuhnya akan semakin berkurang, sehingga harus segera dipasarkan ke konsumen akhir dan pedagang tidak ingin mengambil resiko kerugian untuk memasarkan cumi-cumi tersebut. Sehingga dengan tidak melewati saluran lembaga pemasaran pedagang pasar daerah, cumi-cumi tidak perlu mengeluarkan biaya pemasaran pada pedagang pasar daerah. 
Jika dilihat dari harga hasil tangkapan pada pedagang pengecer, harga ikan cumi-cumi memiliki harga yang paling tinggi dari harga ikan lainnya, yaitu Rp54 400. Kemudian dilanjutkan pada harga ikan kwee sebesar Rp44 400, ikan kembung sebesar Rp39 400, ikan tongkol sebesar Rp34 400 dan ikan kurisi sebesar Rp24 400. Pedagang pengecer merupakan penentuan harga ikan yang diterima oleh konsumen. Biaya pemasaran dan harga ikan pada tingkat pedagang pengecer merupakan indikator untuk menentukan nilai efisiensi saluran pemasaran pada kelima komoditas ikan. Nilai efisiensi saluran pemasaran ikan dapat dilihat pada Tabel 3.

Tabel 3 Nilai efisiensi saluran pemasaran ikan pada bulan Juli hingga September tahun 2016

\begin{tabular}{lccc}
\hline Komoditas Ikan & $\begin{array}{c}\text { Harga Ikan ditingkat } \\
\text { Pedagang Pengecer } \\
\text { (Rp/kg) }\end{array}$ & $\begin{array}{c}\text { Biaya Pemasaran } \\
\text { Ikan (Rp/kg) }\end{array}$ & $\begin{array}{c}\text { Nilai Efisiensi } \\
\text { Saluran } \\
\text { Pemasaran (\%) }\end{array}$ \\
\hline Kurisi (Nemipterus $\mathrm{sp})$ & 24400 & 2692 & 11.03 \\
Cumi-cumi (Loligo sp) & 54400 & 1812 & 3.33 \\
Tongkol (Euthynnus affinis) & 34400 & 1941 & 5.64 \\
Kembung (Restelliger spp) & 39400 & 2131 & 5.41 \\
Kwee (Gnathanodon speciosus) & 44400 & 2249 & 5.06 \\
\hline
\end{tabular}

Sumber : DKP PPP Lempasing (2016), diolah kembali

Berdasarkan Tabel 3 terlihat bahwa harga ikan ditingkat pedagang pengecer yang paling tinggi yaitu pada ikan cumi-cumi kemudian ikan kwee, kembung, tongkol dan ikan kurisi. Dan terlihat bahwa nilai efisiensi saluran pemasaran pada cumi-cumi memiliki tingkat efisiensi yang tinggi yang kemudian dilanjutkan oleh ikan kwee, kembung, tongkol dan ikan kurisi. Hal ini karena ikan cumi-cumi memiliki harga ditingkat pedagang pengecer yang paling besar. Semakin tinggi harga ikan ditingkat pedagang pengecer maka semakin memiliki nilai efisiensi saluran pemasaran yang efisien. Begitu pula sebaliknya, semakin rendah harga ikan ditingkat pedagang pengecer maka semakin rendah pula nilai efisiensi saluran pemasarannya.

Pada komoditas ikan cumi-cumi memiliki nilai efisiensi sebesar 3,33\% sehingga dapat dikatakan bahwa pada saluran pemasaran ikan cumi-cumi memiliki nilai yang efisien dari pada pemasaran pada komoditas ikan lainnya. Hal ini karena biaya pemasaran cumi-cumi relatif rendah dan juga cumi-cumi tidak melewati lembaga pemasaran pada pedagang pasar daerah sehingga tujuan pemasaran ikan cumicumi ini pun tidak terlalu jauh dari pelabuhan tempat pembongkaran ikannya sehingga tidak memerlukan biaya pengeluaran yang tinggi.

Cumi-cumi memiliki biaya pemasaran terendah dari ikan lainnya. Sehingga rendahnya biaya pemasaran ini berpengaruh terhadap tingkat efisiensi saluran pemasaran. Semakin rendah biaya pemasaran yang dikeluarkan pada suatu komoditas ikan maka akan semakin efisien saluran pemasaran ikan tersebut. Jika biaya yang dikeluarkan untuk kebutuhan pemasaran suatu komoditas ikan tinggi maka saluran pemasaran ikan tersebut tidak efisien.

\section{Optimalisasi Fungsi Pelabuhan Perikanan}

Pelabuhan perikanan tidak lepas dari aktivitas pemasaran hasil tangkapan. Aktivitas pemasaran ini meliputi fungsi pemasaran seperti fungsi pertukaran, fungsi fisik, dan fungsi fasilitas. Fungsi pertukaran meliputi pembelian dan penjualan. Fungsi fisik meliputi penyimpanan, pengolahan dan pengangkutan. Kemudian untuk fungsi fasilitas meliputi standardisasi/ grading, penanggungan resiko, pembiayaan dan informasi pasar (Irawan 2007). 
Aktivitas pemasaran hasil tangkapan ini tidak akan berjalan tanpa adanya fungsi pelabuhan perikanan yang mencakup fasilitas, pelayanan dan sistem informasi di pelabuhan. PPP Lempasing memiliki fasilitas pelabuhan yang mendukung dalam pemasaran hasil tangkapan seperti jalan, cold storage, layanan informasi, air bersih, lapak es, tempat penanganan/pengolahan ikan, alat pengangkut ikan (lori) dan tempat pelelangan ikan. Pelayanan hasil tangkapan oleh pelaku pemasaran (SDM yang terlibat) dengan memperhatikan mutu hasil tangkapan di pelabuhan. dan sistem informasi mengenai harga dan kebutuhan pemasaran di pelabuhan.

Perumusan strategi dengan mengidentifikasi kekuatan (strength), kelemahan (weakness), peluang (Opportunities) dan ancaman (threat) dapat dikaji secara langsung dengan melihat kondisi di PPP Lempasing yaitu mengkaitkan fungsi pelabuhan perikanan. Variabel yang berbentuk pada faktor internal dan faktor eksternal adalah sebagai berikut :

Faktor internal ini berupa kekuatan (strength) dan kelemahan (weakness).

Kekuatan (strength) yaitu :

1) Ketersediaan ikan sepanjang tahun

2) Adanya kegiatan atau aktivitas pelelangan ikan

3) Lokasi PPP Lempasing di Ibu Kota Provinsi Lampung

4) Ketersediaan gedung pasar pelabuhan, TPI (Tempat Pelelangan Ikan), gedung pengolahan, dan gudang es

5) Banyaknya pedagang ikan dari berbagai daerah di Provinsi Lampung yang masuk ke PPP Lempasing

Kelemahan (weakness) yaitu :

1) Pengangkutan hasil tangkapan menggunakan lori terbuka ke TPI dan Pasar ikan pelabuhan

2) Minimnya ketersediaan air bersih di PPP Lempasing

3) Lantai TPI dan bakul ikan yang kotor

4) Usaha perikanan tangkap belum efisien dan masih didominasi oleh nelayan skala kecil

5) Pemasaran hasil tangkapan tidak sampai luar Provinsi Lampung

Faktor Eksternal ini berupa peluang (Opportunities) dan ancaman (threat). Peluang (Opportunities) yaitu :

1) Banyak lokasi pemasaran ikan disekitar PPP Lempasing

2) Masuknya hasil tangkapan dari pelabuhan lain

3) Hubungan baik antara pedagang dalam dan luar pelabuhan

4) Pengolahan ikan yang cukup banyak disekitar pelabuhan

5) Menyerap tenaga kerja dan memberikan peluang kesempatan usaha

Ancaman (threat) yaitu :

1) Ketergantungan nelayan dengan tengkulak

2) Kualitas nelayan dan pedagang sebagian besar masih rendah

3) Penggunaan bahan kimia yang dilakukan oleh sebagian pedagang ikan

4) Keterbatasan modal nelayan

5) Kurangnya informasi mengenai data harga dan data lokasi pemasaran ke luar PPP Lempasing

Faktor internal dan eksternal diatas untuk menentukan penentuan keputusan strategi yang kemudian dapat dibentuk matriks SWOT. Dalam matrik SWOT ini, analisis yang dihasilkan merupakan gabungan antara kondisi internal dan eksternal. Matriks SWOT dapat dilihat pada Tabel 4. 
Tabel 4 Matriks SWOT

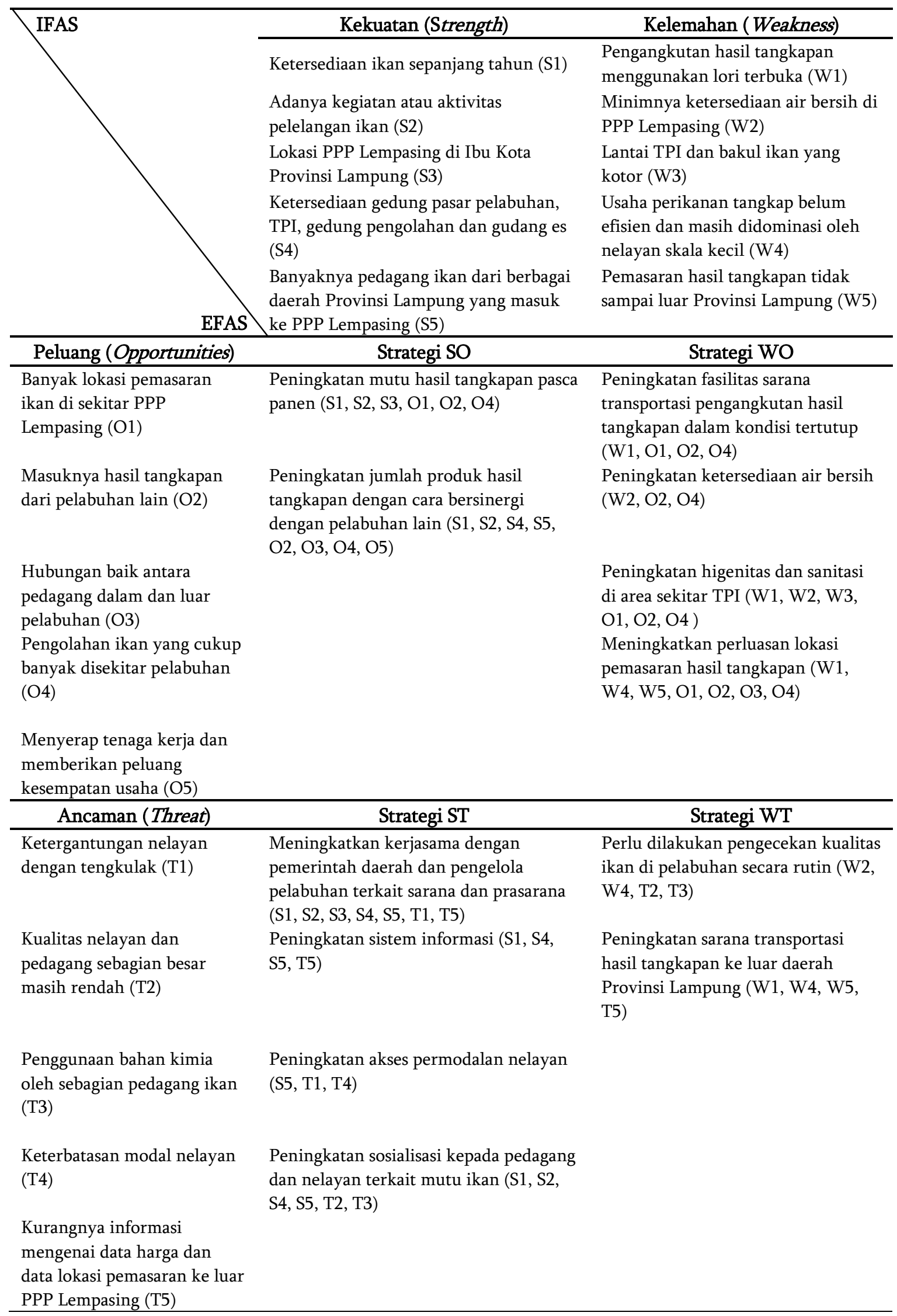


Pada Tabel 4 berikut didapatkan dua belas strategi optimalisasi fungsi pelabuhan perikanan dalam pemasaran hasil tangkapan di PPP Lempasing.

1. Peningkatan mutu hasil tangkapan pasca panen.

Peningkatan mutu hasil tangkapan ini dilakukan dengan cara pemberian es atau dengan mempertahankan kondisi hasil tangkapan agar tetap dalam kondisi suhu yang rendah;

2. Peningkatan jumlah produk hasil tangkapan dengan cara bersinergi dengan pelabuhan lain. Jumlah produk hasil tangkapan dapat meningkat dengan adanya kerjasama dengan pelabuhan lain. Koordinasi sangat diperlukan didalam suatu pelabuhan perikanan. Kerjasama antar pelabuhan lain perlu untuk dilakukan yaitu dengan pengiriman hasil tangkapan dari pelabuhan lain;

3. Peningkatan fasilitas sarana transportasi pengangkutan hasil tangkapan dalam kondisi tertutup. Alat bantu transportasi yang digunakan untuk mengangkut hasil tangkapan dari kapal ke TPI dan ke gedung pasar pelabuhan yaitu dengan menggunakan angkutan lori terbuka. Pelelangan hasil tangkapan dilakukan sampai pada pukul Sembilan pagi, dimana matahari sudah menampakkan sinarnya sehingga jika hasil tangkapan tersebut terkena sinar matahari secara langsung maka akan menurunkan kualitas dari hasil tangkapan tersebut, maka diperlukan lori dalam bentuk tertutup dan berpendingin;

4. Peningkatan ketersediaan air bersih.

Kurangnya ketersediaan air bersih di pelabuhan perikanan membuat pedagang memakai air laut dalam penanganannya. Air laut yang tersedia didekat TPI ini dalam kondisi kotor dan sudah tercemar dari oli sisa bahan bakar dan sisa-sisa ikan yang sudah rusak dibuang ke laut sehingga air disekitar pelabuhan menjadi kotor;

5. Peningkatan higenitas dan sanitasi di area sekitar TPI.

Lantai TPI dibersihkan setiap selesai dilakukan pelelangan ikan dengan menyemprotkan zat infektan pada lantai TPI agar hilangnya kuman atau bakteri. Dan bakul/keranjang yang digunakan untuk meletakkan ikan sebelumnya dibersihkan dari kotoran sehingga ketika digunakan saat pelelangan kondisi bakul/keranjang dalam keadaan bersih;

6. Peningkatan perluasan lokasi pemasaran hasil tangkapan.

PPP Lempasing hanya memasarkan hasil tangkapan di berbagai daerah Provinsi Lampung, memasarkan hasil tangkapan tidak sampai luar daerah Provinsi Lampung (pemasaran hasil tangkapan masih skala local). Perluasan lokasi pemasaran hasil tangkapan ini dapat dilkaukan dengan penambahan jumlah transportasi darat untuk memasarkan hasil tangkapan keluar daerah Provinsi Lampung;

7. Meningkatkan kerjasama dengan pemerintah daerah dan pengelola pelabuhan terkait sarana dan prasarana.

Fasilitas cold storage ada yang tidak digunakan di PPP Lempasing karena tidak cukupnya daya listrik yang dibutuhkan sehingga diperlukan kerjasama pemerintah daerah dari fasilitas jalan raya disekitar pelabuhan perikanan untuk memperlancar proses pemasaran hasil tangkapan. Dan penambahan daya kapasitas cold storage agar dapat digunakan kembali;

8. Peningkatan sistem informasi.

Informasi memegang peranan yang sangat penting dalam manajemen termasuk kegiatan usaha perikanan. Tanpa memiliki informasi yang baik, suatu bidang usaha akan mengalami kemunduran dan kebangkrutan. Sistem informasi penting untuk mengetahui kondisi terkini baik masalah kebutuhan pelabuhan maupun produksi hasil tangkapan dan harga yang berkaitan;

9. Peningkatan akses permodalan nelayan.

Pemerintah harusnya menyediakan bantuan dana terhadap nelayan yang sangat membutuhkan, sehingga nelayan tidak tergantung lagi terhadap tengkulak dan nelayan bisa meningkatkan usaha perikanan tersebut tanpa takut terjerat hutang terhadap tengkulak; 
10. Peningkatan sosialisasi kepada pedagang dan nelayan terkait mutu ikan.

PPP Lempasing jarang sekali melakukan sosialisasi terhadap pedagang dan nelayan. Hal ini disebabnya adanya keterbatasan dana, sehingga sosialisasi sering tidak berjalan;

11. Perlu dilakukan pengecekan kualitas ikan di pelabuhan secara rutin.

Pedagang yang hanya mengambil keuntungan tanpa memikirkan kesehatan pada tubuh menggunakan bahan kimia pada hasil tangkapannya untuk mengawetkan ikan dalam waktu yang lama. Oleh karenanya perlu sekali dilakukan pengecekan hasil tangkapan yang masuk ke PPP Lempasingdan pengecekan dilakukan secara rutin.

12. Peningkatan sarana transportasi hasil tangkapan ke luar daerah Provinsi Lampung.

Hasil tangkapan di PPP Lempasing hanya dipasarkan di daerah sekitar pelabuhan dan hanya di Provinsi Lampung saja, hal ini karena adanya keterbatasan alat transportasi yang digunakan untuk memasarkan hasil tangkapan diluar daerah Provinsi Lampung.

Dua belas strategi yang didapatkan dari analisis SWOT ini kemudian diurutkan sehingga terlihat strategi mana yang menjadi prioritas. Dalam menentukan urutan prioritas suatu strategi tersebut dilakukan dengan menggunakan matriks USG, dianalisis dari tiga unsur USG yaitu Urgency, Seriousness, dan Growth. Berikut matriks USG dapat dilihat pada Tabel 5.

Tabel 5 Matriks USG (Urgency, Seriousness, dan Growth)

\begin{tabular}{|c|c|c|c|c|c|c|}
\hline No & Perumusan Strategi & 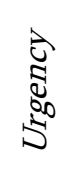 & 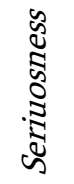 & $\underset{0}{\mathbb{5}}$ & 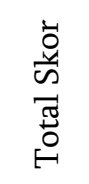 & 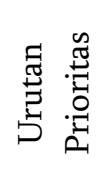 \\
\hline 1 & Peningkatan mutu hasil tangkapan pasca panen & 5.0 & 4.5 & 4.5 & 14.0 & I \\
\hline 2 & $\begin{array}{l}\text { Peningkatan jumlah produk hasil tangkapan dengan } \\
\text { cara bersinergi dengan pelabuhan lain }\end{array}$ & 4.0 & 4.0 & 4.0 & 12.0 & $\mathrm{~V}$ \\
\hline 3 & $\begin{array}{l}\text { Peningkatan fasilitas sarana transportasi pengangkutan } \\
\text { hasil tangkapan dalam kondisi tertutup }\end{array}$ & 4.0 & 4.3 & 4.0 & 12.3 & IV \\
\hline 4 & Peningkatan ketersediaan air bersih & 4.0 & 4.0 & 3.3 & 11.3 & VII \\
\hline 5 & Peningkatan higenitas dan sanitasi di area sekitar TPI & 4.5 & 4.3 & 4.0 & 12.8 & II \\
\hline 6 & $\begin{array}{l}\text { Peningkatan perluasan lokasi pemasaran hasil } \\
\text { tangkapan }\end{array}$ & 3.8 & 4.0 & 3.8 & 11.5 & VI \\
\hline 7 & $\begin{array}{l}\text { Meningkatkan kerjasama dengan pemerintah daerah } \\
\text { dan pengelola pelabuhan terkait sarana dan prasarana }\end{array}$ & 3.3 & 3.0 & 3.5 & 9.8 & $\mathrm{X}$ \\
\hline 8 & Peningkatan sistem informasi & 3.5 & 3.5 & 3.8 & 10.8 & VIII \\
\hline 9 & Peningkatan akses permodalan nelayan & 3.5 & 3.3 & 3.3 & 10.0 & VIIII \\
\hline 10 & $\begin{array}{l}\text { Peningkatan sosialisasi kepada pedagang dan nelayan } \\
\text { terkait mutu ikan }\end{array}$ & 4.3 & 4.3 & 4.0 & 12.5 & III \\
\hline 11 & $\begin{array}{l}\text { Perlu dilakukan pengecekan kualitas ikan di } \\
\text { pelabuhan secara rutin }\end{array}$ & 4.0 & 3.8 & 3.5 & 11.3 & VII \\
\hline 12 & $\begin{array}{l}\text { Peningkatan sarana transportasi hasil tangkapan ke } \\
\text { luar daerah Provinsi Lampung }\end{array}$ & 3.8 & 3.8 & 3.8 & 11.3 & VII \\
\hline
\end{tabular}

Berdasarkan Tabel 5 diatas, maka total skor tertinggi yaitu dengan meningkatkan mutu hasil tangkapan pasca panen, Peningkatan higenitas dan sanitasi di area sekitar TPI serta Peningkatan sosialisasi kepada pedagang dan nelayan terkait mutu ikan. 


\section{PEMBAHASAN}

\section{Tingkat Efisiensi Pemasaran}

Pemasaran hasil tangkapan di PPP Lempasing tidak lepas dari harga ikan dan biaya pemasaran. Masing-masing ikan memiliki harga yang berbeda-beda dengan penanganan yang berbeda-beda pula. Triyanti dan Shafitri (2012) menyatakan bahwa mengalirnya suatu barang dari produsen ke konsumen memerlukan biaya, dengan adanya biaya pemasaran maka suatu produk akan lebih tinggi harganya. Semakin panjang rantai pemasarannya maka biaya yang dikeluarkan dalam pemasaran akan semakin meningkat. Tingginya biaya pemasaran disebabkan oleh kurang tepatnya saluran pemasaran (Rosmawati 2011).

Biaya pemasaran pada masing-masing komoditas ikan memiliki biaya yang berbeda-beda. Pada cumi-cumi memiliki biaya pemasaran terendah dari komoditas ikan lainnya dan memiliki nilai yang efisien. Hal ini karena lokasi pemasaran cumi-cumi hanya disekitar Provinsi Lampung. Sebagaimana menurut Muslim dan Darwis (2012) menyatakan bahwa saluran pemasaran dikatakan efisien apabila biaya yang dikeluarkan merupakan biaya yang relatif rendah terhadap jarak yang ditempuh. Kemudian Irawan (2007) juga menyatakan sistem pemasaran yang efisien adalah dengan menggunakan sumber ekonomi yang serendah-rendahnya yaitu dengan tetap memperhatikan fungsi dari pemasaran tersebut.

Berbeda untuk ikan kwee, tongkol, kembung dan kurisi di PPP Lempasing yang saluran pemasarannya tidak efisien. Hal ini karena biaya pemasaran yang dibutuhkan juga besar meliputi biaya kebutuhan es, air bersih dan transportasi. Selain itu juga komoditas ikan ini melewati pedagang pasar daerah yang cukup panjang. Sebagaimana pernyataan Suparmin et al. (2014) yang menyatakan bahwa biaya pemasaran yang tinggi akan membuat sistem pemasaran kurang atau tidak efisien. Sehingga pemasaran menjadi tidak efisien disebabkan karena banyaknya transaksi yang dilakukan oleh lembaga pemasaran, tingginya biaya pemasaran pada tiap lembaga pemasaran dan kegagalan pasar. Jumlah perantara pemasaran yang terlibat dengan jumlah yang sedikit maka makin cepat, makin murah dan makin efisien hasil tangkapan sampai ke konsumen.

Faktor-faktor yang dapat menjadi ukuran efisiensi pemasaran yaitu keuntungan pemasaran, harga yang diterima konsumen, dan tersedianya fasilitas pemasaran yang memadai untuk melancarkan proses transaksi penyimpanan transportasi serta persaingan antar pelaku pemasaran (Jumiati et al. 2013). Jika dilihat pada Tabel 2 mengenai biaya pemasaran pada masing-masing komoditas ikan. sehingga sistem pemasaran menjadi tidak efisien. Agustian dan Mayrowani (2008) menyatakan bahwa mahalnya biaya pemasaran merupakan akibat dari ketidakefisienan yang disebabkan oleh panjangnya rantai pemasaran dan juga masalah fluktuasi harga yang dialami produsen. Salah satu strategi dengan mengantisipasi belum transparannya harga ikan ditingkat pedagang besar adalah dengan melakukan diversifikasi produk untuk ikan yang melimpah produksinya agar dapat diserap pasar dengan melakukan pengolahan ikan sehingga dapat memperbesar peluang pasar tersebut (Sarwanto et al. 2014).

\section{Optimalisasi Fungsi Pelabuhan Perikanan}

Pelabuhan perikanan pantai Lempasing belum berfungsi secara optimal. Untuk itu perlu dilakukan pengelolaan yang baik agar pelabuhan perikanan yang ada dapat berfungsi secara optimal dalam pemasaran hasil tangkapan. Pengelolaan ini berupa fasilitas, pelayanan dan sistem informasi. Pelabuhan harus memiliki pusat penggerak seperti nelayan, pedagang, pengolah, buruh dan pihak pelabuhan agar pelabuhan dapat dikelola dengan baik.

Pelabuhan perikanan memerlukan pengelolaan yang baik dalam mengoptimalkan fungsi pelabuhan perikanan di PPP Lempasing. Strategi yang perlu dilakukan yaitu dengan peningkatan mutu hasil tangkapan pascapanen. Mutu hasil tangkapan sangat penting dalam pemasaran hasil tangkapan, karena sangat berpengaruh terhadap harga hasil tangkapan. Jika kualitas ikan baik maka hargapun akan tinggi begitu pula sebaliknya jika kualitas hasil tangkapan buruk maka harga ikan pun akan turun. 
Sebagaimana menurut Pane (2008) menyatakan bahwa mempertahankan mutu hasil tangkapan sangat penting untuk dilakukan seoptimal mungkin mulai dari pendaratan hasil tangkapan sampai dipasarkan kepada konsumen akhir. Mempertahankan kualitas hasil tangkapan yang baik akan mempertahankan nilai jual dari hasil tangkapan tersebut. Sehingga untuk menjaga mutu ikan dibutuhkan proses penanganan dan pasca produksi yang baik. Penanganan yang baik yaitu dengan dilengkapi mesin berpendingin atau es curah (Saptanto dan Apriliani 2012).

Hasil tangkapan di PPP Lempasing juga memerlukan transportasi dalam aktivitas pemasarannya untuk tetap menjaga mutu hasil tangkapan. Peningkatan fasilitas sarana transportasi pengangkutan hasil tangkapan dalam kondisi tertutup. Transportasi yang digunakan untuk alat bantu pemindahan hasil tangkapan setelah aktivitas pembongkaran hasil tangkapan ke TPI dan pusat pasar ikan yaitu dengan menggunakan lori terbuka. Hasil tangkapan yang langsung terkena cahaya matahari akan menurunkan kualitas dari ikan tersebut. Sehingga diperlukan alat transportasi yang bisa tetap mempertahankan kondisi hasil tangkapan tersebut yaitu dengan transportasi yang dilengkapi dengan sistem berpendingin. Sebagaimana menurut Murdiyanto (2002) menyatakan bahwa dalam suatu pelabuhan perikanan untuk menunjang kelancaran aktivitas usaha perikanan perlu dilengkapi dengan fasilitas yang mutlak seperti sarana transportasi yang dilengkapi dengan refrigator (berpendingin) sehingga dapat dikelola secara optimal dan dapat meningkatkan laju perekonomian.

Mutu hasil tangkapan akan terjaga jika dilakukan peningkatan higenitas dan sanitasi diarea sekitar TPI (Tempat Pelelangan Ikan). Peningkatan higenitas dan sanitasi ini dilakukan dengan menjaga kondisi fasilitas di pelabuhan untuk tetap dalam kondisi yang bersih. Lantai TPI yang kotor dapat dibersihkan setiap kali mau dan selesai aktivitas pelelangan ikan, kemudian disediakannya tempat sampah. Sebagaimana menurut Murdiyanto (2002) fasilitas kebersihan dan sanitasi dilakukan untuk menjamin kebersihan diareal pelabuhan dan mencegah pencemaran. Saluran pembuangan kotoran dan penanggulangan penumpukan sampah. Untuk menjaga kebersihan dan kesehatan lingkungan maka perlu dibangun selokan, bak sampah dan sistem pengangkutan sampah ketempat pembuangan akhir, pengolahan limbah baik yang berasal dari kapal, tempat lelang, tempat pengolahan ikan serta saluran pembuangan.

Fungsi pelabuhan perikanan ini akan berjalan dengan lancar apabila sumberdaya manusianya juga mendukung dan berkualitas. Sehingga diperlukan peningkatan sosialisasi kepada pedagang dan nelayan terkait mutu ikan. Menurut Manapa (2010) fungsi pelabuhan perikanan yang optimal sangat memperhatikan sumberdaya manusia yang berkompeten dan tangguh dibidang ilmu dan teknologi kelautan. Sehingga dalam memenuhi kebutuhan tersebut maka sosialisasi atau pendidikan mengenai sains penanganan hasil tangkapan harus ditingkatkan. Koordinasi yang dilakukan dalam aktivitas pemasaran hasil tangkapan di lingkungan PPP Lempasing sangat dipenting dilakukan untuk membangun pelayanan yang baik dalam suatu pelabuhan perikanan.

Selain itu juga pentingnya peningkatan sistem informasi yang memegang peranan penting dalam manajemen termasuk dalam kegiatan usaha perikanan. Sistem informasi berbasis internet melalui pusat informasi pelabuhan perikanan memuat informasi mengenai ketersediaan sumberdaya ikan, sarana dan prasarana pelabuhan perikanan, kegiatan operasional dan peluang usaha dari masing-masing pelabuhan diseluruh Indonesia. Selain itu, sistem informasi bisa dijadikan sebagai promosi untuk menarik inverstor diberbagai bidang khususnya dibidang kelautan dan perikanan (Puspitasari et al. 2013). Penyediaan informasi harga pasar yang lengkap dan dapat menjadi acuan bagi nelayan untuk menentukan harga di TPI, sehingga mampu memberikan dampak untuk dapat meningkatkan harga yang diterima nelayan dan dapat meningkatkan efisiensi pemasaran serta pendapatan nelayan (Sarwanto et al. 2014).

Peningkatan peran pemerintah daerah dalam hal penambahan kapasitas daya listrik sehingga fasilitas cold storage dapat digunakan semestinya. Selain itu juga diperlukan berbagai kebijakan oleh lembaga-lembaga yang terkait yang mendukung optimalnya pengoprasian pelabuhan perikanan, baik 
itu dari pemerintah pusat melalui departemen teknis seperti kementrian kelautan dan perikanan maupun dari pemerintah daerah berupa pembangunan prasarana jalan dari dan ke lokasi pelabuhan perikanan, serta perlunya koprasi perikanan. Lengkapnya sarana dan prasarana transportasi dan komunikasi akan memudahkan pelaku ekonomi untuk melakukan aktivitas ekonomi, seperti produksi dan pemasaran.

Peningkatan akses permodalan nelayan perlu dilakukan khususnya bagi nelayan. Keterkaitan nelayan kepada tengkulak berakibat keharusan nelayan untuk menjual hasil tangkapannya kepada para tengkulak tersebut. Septiara et al. (2012) menyatakan bahwa faktor-faktor yang mendukung pemasaran ikan meliputi kondisi fisik dalam suatu pemasaran tersebut, lembaga dan saluran pemasarannya yang terkait, fungsi dari pemasaran dan struktur pasar yang terbentuk. Dengan faktor yang mendukung dapat berfungsi dengan baik maka pelayanan di PPP Lempasing akan tercipta pelayanan yang baik pula.

\section{KESIMPULAN DAN SARAN}

\section{Kesimpulan}

Ikan cumi-cumi memiliki nilai efisiensi yang paling tinggi sebesar 3.33\% kemudian ikan kwee sebesar 5.06\%, kembung sebesar 5.41\%, tongkol sebesar 5.64\% dan ikan kurisi sebesar 11.03\%. Strategi optimalisasi fungsi pelabuhan perikanan terdapat dua belas strategi. Strategi yang menjadi prioritas yaitu meningkatkan mutu hasil tangkapan pasca panen, Peningkatan higenitas dan sanitasi di area sekitar TPI serta Peningkatan.

Saran

Perlu dilakukan upaya meningkatkan mutu hasil tangkapan agar harga tetap tinggi dipasaran. Perlu ditingkatkan sarana dan prasarana pelabuhan perikanan yang mendukung peningkatan mutu hasil tangkapan dalam aktivitas pemasaran.

\section{DAFTAR PUSTAKA}

Agustian A, Mayrowani H. 2008. Pola distribusi komoditas kentang di Kabupaten Bandung Jawa Barat. Jurnal Ekonomi Pembangunan. 1(9):96-106.

Anwar IM. 1976. Dasar-dasar Marketing. Jilid II. Bandung (ID): Alumni Bandung.

Asmoko H. 2013. Teknik Analisis Permasalahan Menentukan Masalah Prioritas. Magelang (ID): BPPK.

Irawan B. 2007. Fluktuasi Harga transmisi harga dan margin pemasaran sayuran dan buah. Jurnal Analisis Kebijakan Pertanian. 4(5):358-373.

Jumiati E, Darwanto DH, Hartono S, Masyhuri. 2013. Analisis saluran pemasaran dan margin pemasaran kelapa dalam di daerah perbatasan Kalimantan Timur. Jurnal Agrifor. 1(12):358-373.

Lubis E. 2011. Kajian peran strategis pelabuhan perikanan terhadap pengembangan perikanan laut. Jurnal Sumberdaya Perairan. 2(5):1-11.

Manapa ES. 2010. Profil dunia kelautan dalam perspektif siswa Indonesia di tingkat sekolah dasar (studi kasus : siswa kelas 4, 5 dan 6). Jurnal Penelitian Pendidikan. 1(11):49-54.

Murdiyanto B. 2002. Pelabuhan Perikanan Fungsi Fasilitas Panduan Operasional Antrian Kapal. Bogor (ID): Institut Pertanian Bogor. 67 hlm. 
Muslim C, Darwis V. 2012. Keragaan kedelai nasional dan analisis farmer share serta efisiensi saluran pemasaran kedelai di Kabupaten Cianjur. Jurnal Sosial Ekonomi dan Kebijakan Pertanian. 1(9):111.

Pane AB. 2008. Basket hasil tangkapan dan keterkaitannya dengan mutu hasil tangkapan dan sanitasi di TPI PPN Palabuhanratu. Jurnal Ilmu Pertanian Indonesia. 3(13):150-157.

Puspitasari N, Ririn I, Adi S. 2013. Strategi pengembangan Pelabuhan Perikanan Nusantara Karangantu Kota Serang Provinsi Banten. Jurnal Ilmu Pertanian dan Perikanan. 1(2):159-169.

Rangkuti F. 2011. Analisis SWOT. Teknik Membedah Kasus Bisnis. Jakarta (ID): PT Gramedia Pustaka Utama Kompas Gramedia Building. 246 hlm.

Rosmawati H. 2011. Analisis efisiensi pemasaran pisang produksi petani di Kecamatan Lengkiti Kabupaten Ogan Komering Ulu. Jurnal Agronomi Bisnis. 5(3):1-9.

Saptanto S, Apriliani T. 2012. Aspek penting dalam pengembangan Pelabuhan Perikanan Samudera Belawan untuk mendukung program industrialisasi perikanan. Buletin Riset Sosek Kelautan dan Perikanan. 2(7):46-53.

Sarwanto C, Wiyono ES, Nurani TW, Haluan J. 2014. Kajian Sistem Pemasaran Ikan Hasil Tangkapan Nelayan di Kabupaten Gunungkidul Provinsi DIY. Jurnal Sosial Ekonomi Kelautan dan Perikanan. 2(9): 207-217.

Septiara I, Maulina I, Buwono ID. 2012. Analisis pemasaran ikan mas (Carassius auratus) di kelompok pembudidaya ikan Kelapa Ciung Kecamatan Cimalaka Kabupaten Sumedang. Jurnal Perikanan dan Kelautan. 3(3):69-73.

Suparmin, Kusrini N, Dolorosa E. 2014. Analisis distribusi pemasaran ikan air tawar hasil usaha budidaya keramba jaring apung (KJA) di Kota Pontianak. Jurnal Ekonomi Sosial. 2(2):69-79.

Triyanti R, Shafitri N. 2012. Kajian pemasaran ikan lele (Clarias $s p$ ) dalam mendukung industri perikanan budidaya (studi kasus di Kabupaten Boyolali, Jawa Tengah). Jurnal Sosial Ekonomi dan Kebijakan Pertanian. 2(7):177-191.

Yulianto CD, Utami DP, Zulfanita. 2013. Pemasaran minyak kelapa di Kabupaten Purwerejo. Jurnal Surya Agritama. 1(1):21-30. 